\title{
Naturalism, Theism, and the Origin of Life ${ }^{1}$
}

\author{
Published in Process Studies, 27:3-4, 1998, 267-279
}

\section{ABSTRACT}

Alvin Plantinga and Phillip E. Johnson strongly attack "metaphysical naturalism", a doctrine based, in part, on Darwinian concepts. They claim that this doctrine dominates American academic, educational, and legal thought, and that it is both erroneous and pernicious. Stuart Kauffman claims that currently accepted versions of Darwinian evolutionary theory are radically incomplete, that they should be supplemented by explicit recognition of the importance of coherent structures - the prevalence of "order for free". Both of these developments are here interpreted in relation to some contemporary theistic notions of "creation", including those of Lewis Ford, Robert Neville, and Robert Sokolowski. Kaufmann's approach is consistent with the approach of process theism, and is not invalidated by the attacks of Plantinga and Johnson. (End of Abstract.)

In Warrant and Proper Function, (WPF) Alvin Plantinga argues that the probability of human cognitive faculties "being reliable (producing mostly true beliefs)" must be regarded as quite low, if "metaphysical naturalism" is taken as valid and "human cognitive faculties arose by the mechanisms to which contemporary evolutionary thought directs our attention" (WPF 219). Since the reliability (proper function) of human cognitive faculties is a precondition of any warranted belief whatsoever, Plantinga concludes that it would be intrinsically irrational to adhere to naturalism and also to the generally accepted evolutionary account of origins. He advocates replacing evolutionary naturalism with a "theistic" approach ${ }^{2}$ 
In Darwin on Trial ${ }^{3}$, Phillip E. Johnson, a professor of Law at the University of California, Berkeley, and an expert on the use of evidence in legal proceedings, examine the evidentiary basis for the currently accepted interpretation of biological evolution, "the Neo-Darwinian Synthesis". He finds that basis decidedly deficient. Among his strongest points is that observations that demonstrate gradual evolutionary changes in specific characteristics (beak shape of finches, color of forest moths, for instance) do not establish how gradual changes could bring about major evolutionary transitions that require concerted functioning of many specialized organs-such as the change from arboreal mammals to night-flying bats, or the origin of life. In a more recent work, Reason in the Balance: The Case Against NATURALISM in Science, Law \& Education (RB), Johnson continues his argument, and makes clear what was implicit in the earlier work. That is that one of the main reasons for his attack on Darwinism is his conclusion that insufficiently critical adoption of evolutionary modes of thought by the majority of scientists, and also by educational (e.g., John Dewey) and legal (e.g., Justice Oliver Wendell Holmes, Jr.) leaders, has led to a highly unsatisfactory cultural situation, and to many evil consequences. Johnson styles himself a"theistic realist" - while distancing his positions from that of the "fundamentalists" and "creation scientists", he accepts the name "creationist"

A creationist is simply a person who believes that God creates-meaning that the living world is the product of an intelligent and purposeful Creator rather than merely a combination of chance events and impersonal natural laws. (RB, 74)

Johnson define naturalism as "the doctrine that nature is 'all there is" (RB, 7) and distinguishes pernicious "metaphysical" naturalism from relatively benign "methodological" naturalism (the strategy of proceeding as if naturalism were true).Johnson contends that the metaphysical disagreement between naturalists and theists-the clash of two incompatible "creation stories"(RB, 12) - is a central issue in a "culture war" now raging in the United States.

Naturalism and theism appear to many thoughtful people as contraries-mutually-exclusive ways of dealing with questions of great significance 4 . But from some points of view, the opposition between these modes of thought, and perhaps even their sharp distinction, may be less clear. Specific notions of deity, and of divine action, that have figured in theistic conceptual systems of long-past civilizations have certainly been influenced by then-prevailing technology-the ways in which people made their living ${ }^{5}$. In our own time, recent developments in science have had major influence on how the object of religion is conceived, at least for some theists ${ }^{6}$. Whitehead wrote:

"....Faith in reason is the trust that the ultimate nature of things lie together in a harmony which excludes mere arbitrariness. It is the faith that at the base of things we shall not find mere arbitrary mystery. The faith in the order of things which has made possible the growth of science is a particular example of a deeper faith. ..." (SMW, 18)

To the extent that this is the case, serious investigators, of whatever sort, employ modes of thought that can be considered to have "theistic" overtones.

Both naturalistic and theistic approaches are in continual change and development-greatly complicating comparison of the two points of view. In particular, the science and technology of the last decades of this century differ in important ways from the science and technology that went just before. In recent decades, theoretical developments and widespread availability of powerful computers have drastically changed the sorts of problems that scientists and 
technologists can tackle, greatly altered the methods they use - and brought about major upheaval in rather fundamental concepts used in scientific work. Major re-conceptualization of causality has occurred. ${ }^{7}$ It seems at least possible that some formerly-serious conflicts between theistic and naturalistic outlooks may well have become moot. This paper reviews a novel approach to the scientific understanding of the origin of life-and to development of biological order and diversity in general-and explores, in a preliminary way, possible relationship between this new approach and some contemporary philosophical theologies of creation.

Richard Dawkins has been engaged in an extended polemic against standard theistic interpretations. Even though he did make what might be called a "theological" contribution ${ }^{8}$ regarding "God's Utility Function", clearly he should be counted as a "naturalist" rather than a "theist". Climbing Mount Improbable, Dawkins' most recent popular work" is mainly a refutation of arguments put forward, over many years, by a number of distinguished physical scientists, who have claimed that biological evolutionary change by natural selection is intrinsically unreasonable, using arguments from probability theory. Dawkins holds that those objections falsely assume that evolution necessarily involves major, abrupt, alteration of a preexisting situation - analogous to a foolhardy mountain-climber essaying an assent straight up the face of a sharp precipice. Dawkins claims that what actually occurs in natural evolution is incremental change, analogous to a more cautious climber's slow assent up a long, but gentle, slope around the back of that steep cliff.

For Dawkins, by far the most important aspect of biological nature is the ability of certain stretches of DNA ("genes") to engender faithful copies of themselves, under conditions that prevail. In earlier works, Dawkins noted that there are other entities in the world, in addition to genes, that have the property of self-replication-units of cultural transmission ("memes") are also "replicators". Recently, Dawkins has re-narrowed his focus to the level of the gene. John Maynard Smith and Eörs Sazthmáry considered five major evolutionary transitions, ranging from the origin of life to the beginnings of human language, using an approach similar to that of Dawkins. ${ }^{10}$

Curiously, Dawkins does not much discuss the work of Stuart Kauffman who, in 1993, published a major work, The Origins of Order: Self-Organization and Selection in Evolution, (OOSSE) dealing with basic mechanisms of evolutionary change. (Dawkins does include brief reference to Kauffman's more popular 1995 work, At Home in the Universe (HU).) Kauffman, like the eminent physicists Dawkins quotes, regards the standard understanding of evolutionary change by natural selection as radically unsatisfactory, but his argument has a quite different structure from the ones that Climbing Mount Improbable rebuts.

Kauffman was trained as a physician. He gave up medical practice to study fundamental questions in biology. "I entered biology because the magnificent wonder of cell differentiation overwhelmed me. (HU, p. 94)." To better understand biological morphogenesis, Kauffman took up computer-modeling of abstract systems designed to mimic important features of biological nature. OOSSE contains rather detailed accounts of computer simulations designed to illuminate a wide range of problems of fundamental biological interest: origin of life, development of mammalian embryos, ecosystem dynamics, etc. HU covers much the same ground as OOSEE, but in a less-technical manner, and it extends arguments based in biology to questions of wider interest, such as the place of humans in the cosmos. As the title of the work indicates, Kauffman concludes that humans are integral parts of evolutionary nature, rather than intrinsically outsiders, as some others - both theists and naturalists - have held.

Kauffman states the opinion that the present general understanding of evolution by natural selection is inadequate. 
.....Where, then, does this order come from, this teeming life I see from my window: urgent spider making her living with her pre-nylon web, coyote crafty across the ridge-top, muddy Rio Grande aswarm with nosee-ems (an invisible insect peculiar to early evenings)? Since Darwin, we turn to a single, singular force, Natural Selection, which we might as well capitalize as though it were the new deity. Random variation, selection-sifting. Without it, we reason, there would be nothing but incoherent disorder.

I shall argue in this book that this idea is wrong. For, as we shall see, the emerging sciences of complexity begin to suggest that the order is not all accidental, that vast veins of spontaneous order lie at hand. Laws of complexity spontaneously generate much of the order of the natural world. It is only then that selection comes into play.......(HU, .7-8)

Kauffman holds that, in addition to dealing with natural selection, any adequate theory of evolution must also account for the spontaneous generation of coherence, what he calls "order for free" (HU, 71-92) His emphasis on this point is a major point of contrast between Kauffman and most other contemporary writers on evolutionary topics

The novelty of Kauffman's approach may be illustrated by considering his discussion of the origin of life. The best known researchers in the field of proto-biology have focused on the currently-prevalent apparatus of biological organization and reproduction - the complex networks of DNA, RNAs, and proteins that constitute present-day biological organisms. They have attempted to infer (or imagine) what simpler states of affairs might have preceded what we now observe. Manfred Eigen's approach ${ }^{11}$ envisions self-reproducing cycles of catalytic and autocatalytic chemical reactions (hypercycles) that undergo modifications that lead to other more-complicated self-reproducing networks of interaction (larger hypercycles). In this view, the predominant direction of evolutionary development is from simpler states of affairs to more complex ones. Enlargement of a hypercycle to produce a larger hypercycle requires that a number of new chemical species come into play. In order for the new hypercycle to function well enough to replace a former hypercycle, these new molecules must each possess quite specific catalytic and autocatalytic functions. Functional constraints of this sort put severe restrictions on the structure and composition that the required new molecules must have This stringency seems to provide some grounds for the type of probability-based anti-evolutionary argument that Dawkins sets out to refute in Climbing Mount Improbable, and also provides some support that the arguments Johnson makes in RB concerning the unlikelihood of major evolutionary transitions occurring solely by Darwinian mechanisms.

At least in part to deal with such points, Eigen more-recently pointed out that each biological genome is not a single sequence of bases on DNA (a unique "point in sequence space") but rather a fairly large number of variant sequences that have quite similar - even indistinguishable - biological functions ${ }^{11} \mathrm{~b}, 11 \mathrm{c}$. Most of these functionally similar sequences differ from the "wild-type" sequence in only one or a few locations, but some have fairly large discrepancies. Rather than being a point in sequence-space, each such "quasi-species" may be regarded as a cloud of such points, with high density in the region of the wild-type but with significant long extensions in several directions. Eigen also points out that biological systems generally operate near what Kauffman calls "the edge of chaos" - that is it usually happens that certain small changes will lead to disintegration of a quasi-species. On this basis, Eigen maintains that abrupt changes of a quite major sort are to be expected in the normal course of events, as a quasi-species centered on one sequence is rapidly replaced by a rather different successor quasi-species centered on one of the extensions of the former species. A formally-similar argument has recently been shown ${ }^{11 d}$ to provide a satisfactory account of the occurrance of major structural changes on binding of a small molecule to an antibody binding site. (In the absence of the small molecule, the antibody has a range 
of possible structures giving rise to a specific consensus sructure: binding the small molecule shifts the probabilities of all those configurations, producing a new consensus structure vastly different from the original one.)

In the case of the origin of life, Eigen's main interest, and also the other major transitions considered by Maynard Smith and Sazthmáry, the closure of cycles of relationships is of central importance - and each such closed cycle has one or more component with the property of self-enhancement known as autocatalysis. A typical autocatalytic change is one in which the product of the change enhances the speed of the process, so that the change keeps getting faster and faster, unless controlled by some other interaction.

Kauffman has an alternative and quite non-standard approach to the question of the origin of life that does not seem to be subject to objections that can be made against prior suggestions. Kauffman rejects the assumption that life began with simple catalytic cycles, such as Eigen originally envisioned. He consider the sort of chemical mélange that is likely to have arisen from spontaneous, garden-variety chemistry on the primitive Earth, prior to the origin of life. Any aqueous solution that contains a large number of chemicals must necessarily give rise to an even more complicated set of chemical reactions between and among those molecules, producing yet more chemical types. On the pre-biotic Earth, it seems likely that there were vast numbers of locations, including many energy-rich ones, where such complex reaction-systems existed. Kauffman argues that, given a sufficiently complex network of reactions, eventually a self-replicating cycle of chemical reactions must necessarily arise. That is, if enough different chemical changes are going on, sooner or later some collection of chemicals must undergo a series of alterations that generates a set of conditions much like the original situation. Once that occurs, that cyclical process will continue indefinitely so long as the conditions do not change greatly. Laboratory experience with chemical networks of this type ( such as the Belousov-Zhabotinski reaction) have shown that such oscillatory reactions are often remarkable tolerant of changes in reaction conditions, within rather wide limits. Closure of such a autocatalytic network of reactions is made more likely, rather than less likely, by increase in complexity of the mixture.

Such a self-replicating cycle would resemble Eigen's hypercycle, in that it would be a closed network of catalytic and autocatalytic processes, but the kind of cycle that Kauffman envisions as the origin of replication is highly complicatednot at all initially simple, as prior workers in the origin-of-life field have tended to assume. The new view holds that the initial closure of a self-replicating cycle was a necessary consequence of the complexity of the situation produced by prior strictly chemical processes, and the cycle that was thus produced was surely large and ungainly. For Kauffman, an important part of evolutionary advance must have been simplification of such initially complex cycles- gradual elimination of ineffective and redundant steps.

On this view there once, before the origin of life, there existed fairly concentrated solutions of molecules-including many carbon-containing ones. Many of these molecules were catalysts, each one facilitating one or more reactions of a wide variety of types. Each of those reactions yielded still other molecules-some catalytically effective in novel ways. Eventually (and necessarily) it happened that some large set of these reactions produced a closed cycle that had the property of regenerating (more or less) the original catalysts and reactants. Such a cycle would keep on going (since it generated its own starting conditions) while other reaction sequences that were not cyclical would play themselves out rather rapidly. Over time, the compounds that were parts of the successful cycle would come to make up larger and larger fractions of the chemicals in the solution. Once established, such a cycle could change by simplification - taking shortcuts around unnecessary steps. By the same reasoning as used previously, the slightly simpler cycle would persist and 
spread, at the expense of the more-complex progenitor. The conditions for simplification of a complex cycle (while maintaining closure) are much less stringent than the requirements for expanding a smaller cycle to produce a larger one. Kauffman proposes that larger cycles may readily be formed by combination of smaller cycles.

The prevailing view holds the plethora of biological forms that now exist have evolved through transitions from simpler autocatalytic reaction-networks to more complex ones. According to Kauffman; the origin of life - and other major evolutionary change - should be envisioned to start from a relatively confused and disorderly state, involving entities of many types, each one a result of previous processes. Since there were many entities in interaction, there were very many ways in which they interacted, and all those interactions had consequences leading to yet further changes. If the situation became sufficiently complicated, the probability that networks of autocatalytic interactions closed - that some novel "dissipative structures" (a term due to llya Prigogine) came into existence - became so large as to approach certainty. All of the changes mentioned depend on the availability of energy, either from a heat-source such as a deepocean hot-spring or from weakly-bonded large molecules produced by prior chemical processes. Once produced, the closed autocatalytic sets of inter-connected changes persisted and expanded their influence, crowding out non-cyclical processes.

The origin of chemical coherence envisioned by Kauffman is related to the origin of coherence of molecular motion in heat-driven convection. When a viscous liquid is heated from below, random motion of molecules transfers heat across the layer. But as the heating continues, eventually a closed loop of molecular movement develops in some region - a column of rising molecules happens to be next to a stack of sinking units - so that a more-or less circular path becomes available. Once that happens, in one small region, the motion of molecules in neighboring regions will be influenced so that the coherent, organized mode of motion spreads - and eventually the whole liquid is covered with hexagonal "convection cells". The spontaneously-organized joint activity transfers heat across the liquid layer much more rapidly than did the original, random motion.

A homely example ${ }^{12}$ may clarify how networks (of chemical reactions, say) would be expected to become simpler with the passage of time, as unnecessary steps drop out. If a sugar-cup is placed near an ant-hill, eventually a roaming ant will stumble onto it. To get back to the nest, the happy explorer will retrace the route used to make the discovery; this route will be a long and winding one. Additional ants will join to exploit the newly-discovered resource - by following the trail of the first ant. Each subsequent ant will follow the path taken by the ant ahead of it, but each will cut corners in doing so. After a fairly short time, the trail from the ant-hill to the food will be as straight as if it had been laid out with a ruler. The final path is quite different from the tortuous route the initial insect had used. In Kauffman's view, the first achievement of any new coherence is likely to be messy; simplicity will only be approached over time - as efficiencies, such as the ant shortcuts, are stumbled upon.

Kauffman's thesis is that growth in complexity eventually, and ineluctably, leads to a situation where coherence on a new level emerges, through closure of a network of catalytic and autocatalytic processes. Once this new type of organization has come into being, progressive simplification is to be expected. Kauffman provides results of experiments - done with computer-models of various types-dealing with biological structure-generation on many diverse levels to support this conclusion.

In Personal Knowledge $e^{13}$. Michael Polanyi writes: 
..the ordering principle which originated life is the potentiality of a stable open system; while the inanimate matter on which life feeds is merely a condition which sustains life, and the accidental configuration from which life had started had merely released the operations of life. And evolution, like life itself, will be said to have been originated by the action of an ordering principle, an action released by random fluctuations and sustained by fortunate environmental conditions. (emphasis in original)

From Kauffman's point of view, the "ordering principle" involved in the origin of life is the closure of appropriate selfreplicating chemical networks ${ }^{14}$.

Strictly speaking, there is no scientific point at issue between Dawkins and Kauffman, the question is one of emphasis. But as Whitehead pointed out, "emphasis is valuation" (PR 313/477). The issue should be understood as "which is more important, the individual replicator (the gene), or the patterns generated by interactions of a myriad of replicators with a complex environment?"

To explain the gaudy colors of certain male maniken birds of the tropics, Dawkins would point to the efficacy of replication of the genes. Kauffman might well observe that it as true to say that the pattern of reproductive behavior ("lekking") characteristic of that species of tropical bird "causes" the set of genes that bird carries, as it is true to say that the nature of those genes "causes" that pattern of behavior ${ }^{14}$. Kauffman would claim that the coherence and efficacy of the macroscopic behavior-pattern (lekking) needs to be taken into account in any adequate understanding of the behavior of those birds, or of their genetic composition. The pattern of behavior that is effective in a lekking bird species is the important "ordering principle", in Polanyi's terminology. The difference of opinion between Dawkins and Kauffman may be understood as a contemporary version of medieval nominalist-realist controversies ${ }^{15}$.

The whole process of spontaneous generation of organization is described by Kauffman as "order for free". Kauffman joins in the proclamation of post-modern science-Nature is self- organizing ${ }^{16 .}$

Howard J. Van Till ${ }^{17}$ recently discussed the relationship of scientific doctrines of "self-organization" to the Christian tradition, particularly to the writings of St. Basil of Caesarea (330-379) and St. Augustine of Hippo (354-430). Van Till's conclusion is that those ancient authors clearly understood that nature has the intrinsic capability to generate novel forms of coherence: both of these ancient churchmen were well able to incorporate this understanding into their theistic philosophies. Van Till describes their view as 'the doctrine of creations's functional integrity". If this is so, why do many find that the notion that nature is self-organizing is somehow contrary to theistic commitments?

The doctrine (widely held until recently) that "matter" itself is fully real (rather than an abstraction, derived from intellectual analysis of concrete really-existing things, as Aristotle held), and that such self-subsistent "matter" is intrinsically inert (as opposed to self-organizing), arguably reached its full flower in the late Renaissance ${ }^{18}$. Part of contemporary divergence between theistic and naturalistic approaches may be understood to arise from overly-complete internalization (by both naturalists and theists) of the cosmology that emerged from the scientific revolution of the seventeenth century - the cosmology in which "matter" was full real, but intrinsically inert. As I have argued elsewhere, this cosmology that is now rapidly being replaced by a rather different one that draws attention to the form-generating capabilities of concrete entities ${ }^{19}$. 
Brief consideration of some recent contributions to the theology of creation may suggest that the divergence between the approaches of Dawkins and of Kauffman to biological questions are at least tangentially related to the naturalism/theism tension. As part of a larger work, Robert Sokolowski ${ }^{20}$ presented a concise summary of "the Christian understanding of the world as created and God as Creator". He points out a major difference between Christian and "pagan" or "natural" ideas of God. For the later, God is "part of the world" — in contrast, for the Christian;

"God is hidden not just because of human psychological limitations, but because he is not one of the things of the world" (p 52).

Joseph Bracken, S.J, John Cobb, Lewis Ford, Charles Hartshorne, Schubert Ogden, Marjorie Suchocki, David Tracy, and others, have developed theological approaches influenced by the thought of Alfred North Whitehead ${ }^{21}$. For Whitehead, God is involved in each event, in the concrescence of every actual entity. God is the source of the "form of definiteness", the "subjective aim", of each occasion. Lewis Ford develops this idea:

....Our freedom lies in the power of the present to select and organize that which we receive from the past.

In the absence of direction, however, such freedom would merely effectuate random combinations of the past. Freedom is responsibly exercised in the light of future possibilities, which become lures in so far as they are valued. Thus we may describe free actualization as the bringing the past into the present by the power of the present responding to the lure of the future. The future is just as causally effective as the past, though each in its own way....... The particular valued possibilities which shape our actions come from many sources, but ultimately, Whitehead argues, they derive from the creative activity of God. God is the ultimate power of the future, rescuing the world from degeneration into chaos by the relentless provision of everlasting new creative possibilities for the world to actualize.......(LG p 36)

Robert Neville 22 find much of process theology unsatisfactory:

My own alternative is that God is the creator of everything determinate, creator of all things actual as well as of things possible Apart from the relative nature the divinity gives itself as creator in creating the world, God is utterly transcendent.... God is the immediate creator of the novel values or patterns by which an event is constituted as the harmonizing of a multiplicity. Since the real being of an occasion is the becoming of a harmonized integration of the multiplicity, its components stem either immediately from God or from what it prehends; since what it prehends are other occasions, themselves analyzable into novel and prehended features, it can be suggested that every feature at some time in the present or past is or was a spontaneous novel pattern or value immediately created by God. Thus God is the creator of every determinate thing, each in its own occasion of spontaneous appearance. ( CG p. 8)...

On the basis of such considerations, Neville describes his approach as creation ex nihilo. Neville maintains that God transcends the world but is related to each and every created thing as the creator of that thing:

Another kind of relation, however, obtains between two things, one of which is the creator of the whole being of the other... The created thing would have no integrity over against the creator, since against the 
creator it would have no being, but it would have the integrity of being exactly what the creator creates it to be... (CG $p$ 82.)

Although Neville differs from traditional Christian theistic doctrine in important ways (such as dealing with the personal nature of God), he asserts transcendence in a way that Ford does not seem to do,

Kauffman's understanding of evolution seems much more conducive to theistic understanding than is Dawkins' approach. The dipolar deity of process theology, as developed, for instance, by Lewis Ford, appears to fit rather well with Kauffman's "order for free". Intrinsically new coherences arise from chaotic antecedents at many levels in the course of the development of every biological organism, and ecological community. Kauffman calls attention to the importance of understanding this sort of spontaneous order-generation and its causes. Much of what Ford says about "the lure of God" could be transferred into Kauffman's conceptual scheme. Sokolowski clearly would regard Ford's approach as excessively "naturalistic" ( a characterization that Neville also employs). Neville claims that his system preserves both the divine transcendence that Sokolowski insists upon, and also the intimate relationship between creature and creator that Ford's system provides. Each of these three theistic authors is engaged in a difficult but necessary task, the attempt to craft a conceptual scheme adequate to the full range of contemporary human experience, giving appropriate attention to the valuable insights of venerable theistic traditions.. Both Dawkins and Kauffman, as scientists, focus more sharply on their biological and modeling data - but they both claim that their work is relevant to more general human concerns.

Plantinga and Johnson aim to defend theism by attack on evolutionary naturalism, which they consider to be antithetical to their notions of God and divine action in the world. In so doing they tend to emphasize God's involvement in the major evolutionary transitions - changes that, by any account, are wonders and marvels - but they seem to neglect God's action in more mundane matters, such as the arrival of Spring in the woods, or a toddler's rapid mastery of language ${ }^{23}$ - events that many find to be fit sources of wonder and marvel. Neville takes pains to make clear that while God is necessarily involved in each natural event (remarkable or not), but that God is, as Sokolowski requires, "not one of the things of the world." In a sense, this approach falls under Johnson's definition of metaphysical naturalism, since it turns out that nature is all there is in the world, since God is not. A deity that mainly operated in major transitions (as seems to be tacitly assumed by Johnson) seems to be "one of the things of the world" more than does the deity envisioned either by Neville or by Ford.

Johnson is surely correct that the scientific evidence for the current understanding of the origin of life - and other major evolutionary transitions - is incomplete, at best. From a legal point of view, the Scotch verdict "not proven" surely seems appropriate-as it would be for very many other major items in current science. The wide and growing acceptance of the evolutionary outlook indicates that it is a highly suitable platform for "stories scientists tell". Those stories, even if few reach even close to certain and irreformable knowledge, are in our day, adding up to a highly coherent account of the world and its functioning.

Even if not quite all of the deleterious societal consequences that Johnson recounts can be laid solely at the feet of "Darwinism", it is surely true that some of them can. As might be expected, religious, educational, and other social institutions require time to adjust to intellectual changes, such as the vast increase both in human understanding and in the scope for human action (for both good and ill) that modern science and technology have made possible. Theists quite properly see the hand of God at work in major evolutionary changes such as the origin of life, but also in such every-day occurrences as the development of a fertilized egg into a cocker pup, and also in the social turmoil-including very real moral and physical evil that accompanies economic, technological, and intellectual change. Process theism, such as that 
of Lewis Ford and his colleagues seems the best present means to provide interpretation (at once theistic and naturalistic) that extends to all events, including major evolutionary developments-and might even provide an adequate theological and philosophical basis to moderate some culture-war hostilities.

\section{References}

Ford, Lewis. The Lure of God: A Biblical Background for Process Theism, Fortress, 1978.(LG)

Johnson, Phillip E.Reason in the Balance: The Case Against NATURALISM in Science, Law \& Education (Downers Grove, III: Intervarsity Press, 1995.)(RB)

Kauffman, Stuart. The Origins of Order: Self-Organization and Selection in Evolution. (Oxford: Oxford University Press, 1993). (OOSEE)

Kauffman, Stuart. At Home in the Universe. (Oxford: Oxford University Press, 1995) (HU)

Neville, Robert. Creativity and God: A Challenge to Process Theology, New Edition (Albany: SUNY Press, 1995) (CG)

\section{Notes}

1) An earlier version of this paper was presented at the Conference: Naturalism, Theism, and the Scientific Enterprise (NTSE) held at Austin, Texas, March 20-23, 1997 under the title "A New Approach to Biological Evolution and Some Concepts of Creation". Papers presented at the NTSE conference are available for downloading at http:// www. dla. utexas. edu/ depts/ philosophty/ faculty/ koons/ ntse/ main.html.

2) See also: Plantinga, Alvin. Warrant: The Current Debate. (New York, Oxford University Press, 1993.)

3) Johnson.Phillip E. Darwin on Trial (revised ed., Downers Grove, Ill: Intervaristy Press, 1993).

4) Many of the papers at the NTSE Conference (note 1) illustrate this point.

5) Levi-Strauss, Claude. Tristes Tropiques translated by J. and D. Weightman. (NY: Atheneum, 1974)

5) Renfrew, Colin "The Archaeology of Religion" in Renfrew and Zubrow, eds. The ancient mind; elements of cognitive archaeology. (Cambridge, Cambridge University Press, 1994).

6) Haught, John, Science and Religion: From Conflict to Conversation. (NY, Paulist Press, 1995).

7) Theological implications of developments of this sort have been discussed in a recent Vatican Observatory publication: Russell, Robert; Murphy, Nancy; Peacocke, Arthur, eds Chaos and Complexity, Scientific Perspectives on Divine Action, (Notre Dame, Indiana: Vatican Observatory Publications, 1995)

8) Dawkins, Richard. River Out of Eden. (London: Weidenfeld and Nicholson, 1995)

9) Dawkins, Richard. Climbing Mount Improbable (NY: Norton, 1996.)

10) Maynard Smith, John and Sazthmáry, Eörs. The Major Transitions in Evolution, (New York. Freeman, 1995).

11) a) Eigen, Manfred with Winkler-Ostwatisch, Ruthild (trans. Paul Wooley), Steps Towards Life: A Perspective on Evolution. (New York: Oxford University Press, 1992).

b) Eigen, Manfred. "Viral Quasispecies". Scientific American, 269, 42-49, (July) 1993.

c) Eigen,Manfred. "The Origin of Genetic Information: Viruses as Models", Gene, 135 (1993), 37-47. 
d) Wedemayer, Gary J.; Patten, Phillip A.; Wang, Leo H.; Schultz, Peter; Stevens, Raymond C. "Structural Insights into the Evolution of an Antibody Combining Site", Science 276, 1997, 1665-1669

12) Bruckstein, Alfred M. "Why the Ant Trails Look So Straight and Nice", The Mathematical Intelligencer, 15\#2 (Spring) 1993, 59-62.

13) a) Polanyi. Michael Personal Knowledge: Towards a Post-Critical Philosophy. (London: $\quad$ Routledge \& Kegan Paul, 1958b)

b) Haught J. F. and Yeager,D. M.. "Polanyi's Finalism", forthcoming in Zygon (personal communication from J. F. H.)

14) McDonald, David B and. Potts, Wayne K."Cooperative Display and Relatedness Among Males in a Lek-Mating Bird". Science 266 1030-1032, 1994 (11 November)

15) Wilson, Edward O., "Biological and Human Determinants of the Survival of Species", in Joseph. E. Earley, ed. Individuality and Cooperative Action. (Washington: Georgetown University Press, 1990).

16) Randall, John H., Jr.. The Making of the Modern Mind, New York: Columbia Univ. Press, 1926, pp 101-102.

17) Van Till, Howard J. “Basil, Augustine, and the Doctrine of Creation's Functional Integrity”, Science and Christian Belief, 8, 21-38, 1996.

18) a) Leclerc, Ivor The Nature of Physical Existence, (New York: Humanities Press, 1972)

b) Ferré, Frederick. The Matter with Matter. (Nobel Conference XXXI, October , 1995).

c) Ferré, Frederick. Being and Value: Toward a Constructive Postmodern Metaphysics. (Albany: State University of NewYork Press, 1996)

19) a) Earley, Joseph ) "Collingwood's Third Transition: Replacement of Renaissance Cosmology by an Ontology of Evolutionary Self-Organization" in With Darwin beyond Descartes-The Historical Concept of Nature and Overcoming "the Two Cultures". L. Zanzi, ed, Pavia Italy, forthcoming.

b) Earley, Joseph “How Do Chemists Know When 'Many' Become 'One'? Can Others Do It Too?"Philosophy of Chemistry and Biochemistry, N. Psarros, ed,(Wuerzburg: Koenigshausen and Neumann, forthcoming 1997).

20) Sokolowski, Robert, Eucharistic Presence: A Study in the Theology of Disclosure, Washington, Catholic University Press, 1993.

21) a) Cobb, John B. Jr. and Griffin, David Ray. Process Theology: An Introductory Exposition.(Philadelphia. Westminister Press, 1976.

b) Sia, Santiago, Ed. Process Theology and the Christian Doctrine of God,(Petersham, Ma., St. Bede's Publications, 1986) (Word \& Spirit, vol.8)

c) Bracken, Joseph, S.J. and Suchocki, Marjorie eds Trinity in Process

22) Neville is influenced by Paul Weiss, by Eastern thought, and by John Smith and the American pragmatist tradition.

23) Rom Harré and Daniel Robinson. "What Makes Language Possible. Ethological Foundationalism in Reid and Wittgenstein", Rev. Metaphys.,50.3, 483-483 (1997). In this view human language is connected, in its origin with "natural signs" (facial expressions, postures, etc.). To the extent that this is the case, the reliability of human communication, and hence the reliability of beliefs, is itself a result of a long evolution. 
